\title{
The Right to Democracy Arrangement Under International Law
}

\author{
Rika Kurniaty \\ Ritsumeikan University, 56-1 Toji-in Kitamachi, Kita-ku, Kyoto 603-8577, Japan \\ Brawijaya University, Department of International Law, Faculty of Law
}

\begin{abstract}
In the historical context, during the Cold War, due to the tension of ideology between countries, the link between international law and the notion of democracy only received few discussions and interest by international law scholars. The fall of communism in the early 1990s has put liberal democracy - as the only legal system of government - back on the global agenda. The victory of democracy throughout the world quickly led to the claim that there is now a right to democracy in international legal instruments and the existence of democracy as a guiding principle in general international law. However, the word "democracy" does not appear in the Charter of the United Nations and in the Covenant of the League of Nations. There is no standard textbook on international law that contains chapters on democracy. The International Court of Justice does not base its decisions on applying the principles of democratic rule. If one does not look beyond the pillars of international law, one could conclude that democracy is irrelevant. In maintaining that all communities are entitled to democratic governance, this paper will examine arrangements for the right to democracy in international law, especially under the Universal Declaration of Human Rights, which is recognized by the international community.
\end{abstract}

Keywords: The right to democracy, international law, Universal declaration of human rights

\section{Introduction}

Under the international legal

framework, the concept of democracy did not find its way in the United Nations (UN)

Charter; however, the idea of democracy was included in other constitutive international instruments of the postwar period. It is commonly acknowledged that the end of the Cold War shifts an opening for a further pattern in the global search for peace and security (Ezatah, 1997). An examination of the old and enduring statist paradigm belies the general assumption that most countries have unity of identity, population, government, and territory. However, the new imperatives of justice, human rights, and self-determination have challenged the old paradigm order. Many scholars assert that human security and peace could be found only in the context of rooted injustice and human development, namely in the democratic peace where every party has the right to democracy.

Traditional international law has been neutral towards the concept of the right to democracy, which it almost does not pay attention to the democratic legitimacy of its most important subjects - the state. 
International law is only concerned with relations between States and not within them. Based on the classic concept of sovereignty, States are given full authority to elect their government. However, since the early 1990s, democracy has become a fascinating topic in law and international relations. Many scholars assert the end of communism in the Soviet Union and elsewhere has been described as the victory of global democracy.

Many scholars, especially Western scholars, have widely discussed the issue of the right to democracy. There is a consensus between them regarding the right to democracy existence, also on the legitimacy of collective interventions for the restoration of democracy (Fox, 2007). Some of them support unilateral interventions for the protection of democracy (Reisman, 1995). If unilateralism is illegal according to the provisions of article 2 of the UN Charter, and contrary to the normative principle of collective security in which the UN system is established (Falk, 1995), scholars recognize that there is an international right to democracy that could be protected by a collective intervention. Besides, global and regional human rights instruments have also ratified the right to democracy.

\section{Research Methods}

This article is literature study by using the statute approach specifically the Universal Declaration of Human Rights. This article aims to discuss and examine how the right to democracy is recognized and positioned within the framework of international law. This article comprises of five-section, which will discuss the sovereignty and self-determination of state, the right to democracy in the Universal Declaration of Human Rights, the right of intervention, and finally, the conclusion. Following this introduction, the next section below will discuss sovereignty and selfdetermination of state.

\section{State sovereignty: from traditional conceptsto its development}

The notion of the right to democracy has close links with the sovereignty of the state and the right to self-determination. Based on the positivist agreement theory, international law is a system of rules accepted or approved by sovereign states to bind it through customary law. International law is traditionally based on the principle of equality of a sovereign state, where a sovereign state has the exclusive right to exercise power with its territory, citizens, and resources. International law, as a rule of 
coordination, therefore prohibits the existence of protection or external intervention from an equal and independent state. This principle of non-intervention is enshrined in Article 2 (7) of the UN Charter, which states that the Charter does not provide competence to the $\mathrm{UN}$ or to $\mathrm{UN}$ Members, to intervene in matters primarily falls under the national jurisdiction of a State. Under Article 2 (7) of the UN Charter, the state is not authorized to impose democracy by force. The choice of constitutional model is clearly an issue that is basically in the national jurisdiction. As such, any attempt by democratic States to force by force the democratic model on socalled "non-democratic" countries would violate the principle of equality and nonsovereign intervention.

Furthermore, since the end of the Cold War, the international community has been involved in two tasks that contradict the traditional notion of state sovereignty. The first is the reconstruction of domestic political institutions in countries that have emerged from civil war. The second is the promotion of liberal democracy as a preferred form of the national government. Whether one understands state sovereignty in territorial or functional terms, both tasks open new paths. At the heart of most of the
Peace Westphalia conception of the state, autonomy is the capacity for selfgovernment.The notions of sovereignty and non-intervention in the internal affairs of a country are thus a significant obstacle to the development of democratic principles of international law. Furthermore, there are some events, which are indicative of a shift in the relationship between the concept of state sovereignty and non-intervention on the one hand, and human rights and humanitarian interventions (including prodemocracy interventions) on the other.

Moreover, based on the idea of sovereignty, state has political and legal status as an independent entity. Selfdetermination thus, is done through the formation of an independent state (Przetacznik, 1991). The norm of selfdetermination guarantees the right of a nation or nation freely to determine its destiny without any interference. The conception of self-determination is like the two sides of a coin. On the one hand, this means political independence from alien domination or an existing sovereign state. While on the other hand, the right to determine fate requires people's democratic choices regarding their governance (Stromseth, 1992). The self-determination has a normative status that is adhered to (Jus 
Cogens) in international law and can only be ruled out by subsequent mandatory norms that apply otherwise. Therefore, the right to democracy as an internal aspect of the right to self-determination for all societies and countries can be correctly classified as the primary international customary law. The nationalist aspects of self-determination dominated the Cold War period, bipolar as a result of sensitive political and ideological questions about colonies and territories without self-government, the notion of internal self-determination as customary international law has been experienced in obscurity.

It was during the Cold War, international law must remain neutral, dealing with the internal character of each political model, because it is in the realm of domestic politics and law, rather than being the domain of international law (Fijnaut et al., 2004). After the collapse of the communist regime in the Soviet Union and Eastern Europe in 1989 to 1991, the neutral position of international law, vis-a-vis the form of internal governance of a country, has shifted from the traditional concept of state sovereignty (sovereignty in the hands of the state regardless of their constitutional arrangements) towards the concept of popular sovereignty based on citizen consent
(Fox, 1992).According to Bhagwati (1997), globalization also has a significant impact on traditional international law and the concept of national sovereignty through global economic integration in trade and investment. Liberalization of trade and foreign direct investment, multinational corporations have increasingly gained the power of political negotiations and privileges obtained from developing countries (Stiglitz, 2003). Regulation of global problems (i.e., global warming, terrorism, drug trafficking, weapons of mass destruction, and human rights violations) has now developed outside the national jurisdiction of a country (Singer, 2002).

After the end of the Cold War, the international agenda to ensure human rights (including the right to democracy) has gained momentum. There is increased recognition and awareness of interdependence among people and the interconnection of global challenges, which has led to a more integrated approach to solving global challenges related to international peace and security, global warming, human rights, and governance (Marcos, 2004). Thus, the state is now expected to adhere to basic democratic standards. The international community of interdependent countries provides broad 
support to ensure the protection of fundamental human rights. This support was obtained mainly from the actions of international organizations together with individuals and non-governmental organizations, which called for greater participation in the governance process, which impacts on people's lives in general (Held, 1995). This shift in ideas has led to the emergence of various scholarly opinions, one of which states that there is a shift from the traditional principles of sovereignty and non-intervention that support human rights, including the right to democratic governance, and humanitarian intervention. Also, that international law allows an active state to unilaterally free people from despotic governments in other countries (ibid).

\section{The right to democracyin the framework} of the UDHR

\section{a) An historical context}

The coherent status for the concept of democracy thatfunctioning as a principle of the order of international law is in human rights law. The Universal Declaration of Human Rights (UDHR) is the main instrument of the right to democracy and contains the most definite statements about the problem of democracy. Although
General Assembly resolutions are often considered non-binding, it must be noted that the UDHR is not just like another General Assembly Resolution. The UDHR has inspired regional and international agreements outside national borders. The UDHR has effectively removed any stigma that attended the circumstances of its birth. According to the United Nations, the most extensive law binding human rights treaties (in this case the International Covenant on Economic, Social and Cultural Rights and the International Covenant on Civil and Political Rights) have taken the provisions of the UDHR one step further by making them binding on States parties. Universal acceptance of the UDHR is an opinion that is sufficient Juris for customary binding rules of international law. In this regard, the UDHR is seen as having evolved into the center of the international human rights movement and the main normative international instrument on this issue.

Furthermore, the right to democracy gained extra momentum when UN Secretary-General Boutros Boutros-Ghali submitted the Agenda for democratization to the UN General Assembly. (Russet, 1997) Boutros-Ghali convinced that the right to democracy existed and was intended to clarify opinion Juris, which was required to 
have new established customary international norms. In the Agenda for Democratization, Boutros-Ghali pointed out that the aim and principles of the United Nations are to promote democracy and that the principle of non-intervention from Article 2 (7). The Charter does not aim to uphold the national democratic model but to provide support and advice to countries regarding democratization.

Furthermore, the idea of right to democracy could no be separated from the participatory right. All human rights laws present challenges for the traditional notion of state sovereignty, which this case, the right to participate is politically not exclusive. Nevertheless, participatory rights involve not only specific boundaries on state sovereignty in certain fields but also more fundamental issues about who holds sovereign authority in a country. The right to participate states that the mass of citizens is the highest holder of sovereignty.

It is argued that participatory rights have created critical tensions in international law. Two sets of factors could explain traditional exceptions to participatory rights from international law, which is common to all human rights norms, and the others are specific to the rights themselves. International human rights law emerged after the Second World War, the product of events such as the Nuremberg Trials, the establishment of the United Nations, and the ratification of the UDHR by the United Nations General Assembly in 1948.

Before the Second World War, apart from in some exceptional cases, where individuals are allowed to prove their rights directly under special international treaties, individuals are not subject to rights and obligations under international law. Individual rights to participate in government do not and could not emerge in this international legal climate. The way countries choose their leaders forms the main characteristic of protected domestic space. Democratization found its ultimate expression during the 18th and 19th centuries. A contributing factor to the delay in the emergence of participatory rights in international law is that national elections did not become common until the mid-19th century. General requirements for free and fair elections cannot reasonably be expected to emerge until general elections in each country become the norm. However, until the mid-twentieth century, many countries were still involved in national debates about the nature, power, and breadth of representative institutions.

b) The UDHR substance of democracy 
The UDHR lays out the civil, political, economic, social, and cultural rights of all people, such as the right to democratic governance, social security, employment, the standard of living, food, clothing, housing and adequate medical care, education, and cultural development. The basic principle of the right to democracy and political participation are set out in Article 21 of the UDHR, which describes the will of the people as the basis of a government authority also calls for the will to be seen through periodic and general elections. Therefore, a government that is not based on an agreement of the people is categorized as an undemocratic government. Also, the government must substantially represent all different groups. In order not to lose the essence or damage the ethical concept of representation, we must examine the tendency to assume the actual representation of nominal representations. It is worth noting that the representation must be manifested in active participation or popular participation.

The United Nations has defined the right to popular participation as a constitutional and political structure that allows all citizens to participate freely and actively. The popular participation is critical in laying the constitutional foundations of the political community. Also, determining the scope and objectives of various institutions and electing their leaders to govern the State. Under international law, the emerging government must be based on popular consent and must be participatory in representing all national and different political groups in the country. A critical assumption for this standard is government, and legal representation of government is a substantive component of universal democracy, both components are needed to maintain the sanctity and territorial integrity of a country which cannot be disturbed.

Article 21 of the UDHR stipulates general elections, which are periodic and pure with universal and equal suffrage and with the secret ballot, as the only process by which democracy can be achieved. Governments that obtain or retain power by any other process are undemocratic and thus invalid in international law. In short, the legitimacy of the government must be periodically tested through elections. Furthermore, a structural element makes it compulsory for countries that want to join a circular democracy to arrange their governance in a normative and institutional framework that provides for the welfare of the people. 
Moreover, observation of the principle of Article 21 entered into the form of binding agreements in Article 25 of the International Covenant on Civil and Political Rights (ICCPR) - establish procedures for mechanisms that enable democracy to develop. Interpretation of General Comments on Article 25 represents a considerable strengthening of democratic ideals; adequately implemented, the provisions will ensure free and fair elections. Freedom of expression and association (paragraph 12) are required; perpetuating non-discrimination in relation to the right of citizens to vote (paragraph 3); refuse all conditions for voting or running for political affiliation (paragraph 15); calling on voters to freely support or oppose the government without any undue influence or coercion (paragraph 19), and requires countries which report under the Covenant to explain how different political views in society are represented in elected bodies (paragraph 22). The General Comments provide jurisprudence that moves the Covenant's obligation to hold periodic elections.

Article 25 of the ICCPR states that every citizen has the right to take part in the conduct of public affairs, directly or through freely chosen representatives. Article 25
ICCPR could be found at the regionallevel in Article 3 of Protocol I of the European Convention on Human Rights, and in Article 23 of the American Convention on Human Rights. however, during the Cold War confrontation, Article 25 of the ICCPR was not given ordinary and natural meaning. In 1996, the United Nations Human Rights Committee, an expert body formed by the ICCPR, adopted a general explanation outlining rights to democracy in Article 25.

Interpretation of General Commentary on Article 25 represented the strengthening of an ideal democracy; adequately implemented, the provisions will ensure free and fair elections. Freedom of expression and association (paragraph 12) are required some conditions. Among them is 1 . perpetuating non-discrimination concerning the right of citizens to vote (paragraph 3); 2. refusing all conditions for voting or running for political affiliation (paragraph 15); 3. calling on voters to freely support or oppose the government without any undue influence or coercion (paragraph 19); 4. requiring countries which report under the Covenant to explain how different political views in society are represented in elected bodies (paragraph 22). This general explanation provides jurisprudence, which gives strength to the Covenant's obligation to hold periodic 
elections and electoral democracy. The effectiveness of electoral democracy, when combined with compliance with other obligations in fundamental human rights treaties, results in a functioning liberal democracy.

Furthermore, Article 28 states that a person is entitled to a social and international order in which the rights and freedoms outlined in this Declaration can be fully realized. From the primary integrative language and article 28 , it is clear that each article must be interpreted in the context of the UDHR ration. Accordingly, article 21 means the right to a democratic system that guarantees the rights provided for in articles 22 to 27 , as required by article 28 . In short, articles 21 and 28 jointly define a democratic state in international law as a state that has conditions. Substantive content, procedural content, and structural content, constitutional and institutional frameworks that guarantee each individual's rights provided for in articles 22 to 27).

\section{Right to Intervention}

In examining the right to democracy in international legal instruments, it is essential also to look at regulating the right to intervention into a country. This right to intervention is related to the previous discussion about sovereignty and the right to self-determination. The Vienna Declaration and Program of Action adopted by the World Conference on Human Rights in 1993 are affirmed in paragraph 8 of Part Istates that democracy, development, and respect for human rights and fundamental freedoms are interdependent and mutually reinforcing. The international community must support the strengthening and promotion of democracy, development, and respect for human rights and fundamental freedoms throughout the world. Although it is a nonbinding instrument, this Declaration is a clear indication of the direction of international opinion and the development of international law.

As mentioned above, the right to democratic governance is borne by article 21 of the UDHR. However, the responsibility of the state must still be determined. Traditional international rules state that a country is not guilty of violating international law because it hurts one of its citizens. Thus a country that denies its citizens the right to democracy is protected from international scrutiny. The founders of the United Nations did try to familiarize and expand this traditional internal sanctity. Article 15, paragraph 8 of the Treaty of Nations, which regulates not to intervene in 
matters under international law within the scope of domestic jurisdiction, is replaced by article 2 (7) of the Charter. Article 2 (7) does not, by itself, allow the scope of internal matters to be determined by international law, but instead chooses vague and expansive phrases basically within domestic jurisdictions. However, contemporary practice shows that international law has moved beyond these traditional boundaries, and now there are several reasons to justify the multilateral protection of democracy. When the rejection of democracy is carried out by oppression by force, state practice shows that there is a right of intervention based on the human imperative and the right to defend the people.

Articles 55 and 56 of the UN Charter and Article 1 of the Covenant on Civil and Political Rights stipulate that all state parties have legal interests and obligations to ensure the protection of human rights. Also, the right to self-determination within the boundaries of member states. These provisions could legitimize multilateral actions given that the right to democracy is an aspect of the norm of self-determination. The protection of democracy could be justified under the positive obligation "erga omnes" of all countries in international customary law to protect the country's internal self-determination. The normative status of this peremptory norm is now being questioned in such a way that the ordinarily passive International Court of Justice, in one case, indicates its readiness to include a Charter or the authority exercised under it. However, if such action is to be forced into the statement of Chapter VII, the "domestic jurisdiction" in article 2 (7) and the "threat" to the "restriction of international peace" in article 39 of the Charter will be summarized by the primary responsibilities placed on the state to protect democracy by the norm of self-determination.

Furthermore, the legality of the intervention could be sought in article 24 of the UN Charter, which has been interpreted as giving general strength beyond specific powers in Chapters VI, VII, VIII, and XII. However, restrictions on actions taken are presently based on Chapter V article 24 inclusive. The limitations in article 24 (2) specify that the US Security Council acts following the aims and principles of the Charter. This goal can be legitimately summarized as "humanism" and the principles of "collectivism." In other words, any action taken by the Security Council must be informed by the main interests of the people of the target country. 
Furthermore, interventions must be multilateral or collectively subject to sanctions under the supervision of the United Nations. Finally, the intervention must not violate a general domestic jurisdiction clause, which is permitted when interventions are carried out following articles 39, 48, and 51 in Chapter VII.

Since the end of the Cold War, state practice seems to have agreed to the principles of article 15 (as discussed above) as the basis of domestic jurisdiction. What is called an "internal problem" is increasingly becoming a determination of international law. Where the issue of human rights is only an item of domestic jurisdiction can no longer be debated, and the legitimacy of individual governments has gained international relevance. Given the standards for government legitimacy and internal sovereignty as the will of the people, international legal instruments must be interpreted as validating international regulations and protecting those standards. Besides, the Declaration on the Principles of International Law Regarding Friendly Relations makes a country's territorial integrity dependent on its ownership of consensual representative governments.

\section{Conclusion}

In summary, the fundamentals of the right to democracy have long been established in human rights instruments, especially the International Covenant on Civil and Political Rights (ICCPR). The status for the concept of democracy that will be expanded as anoperativenotion of the international legal order is in human rights law. If we refer to the legal norms embedded in international conventions and declarations, it is clear that the right to democracy is implied by the provisions of the Universal Declaration of Human Rights (UDHR) of 1948 in article 21, which protects "the right of all people to participate." The basic principle set out in Article 21 of the UDHR is described as the will of the people, or the basis of government authority, or a call for it to be distinguished through general elections and periodic elections. Article 21 of the UDHR establishes a solution to the problem of representation by stipulating that everyone has the right to take part in government. This provision shows active participation, which is usually expressed through free elections.

Besides that, more explicitly is the contents of the International Covenant on Civil and Political Rights (ICCPR) in Article 
25 , which states that "the right to vote by all citizens" is elevated to binding international legal norms. Similar provisions are found in regional human rights instruments such as the American Convention on Human Rights (1969, Article 23) and the African Charter on Human Rights \& People's Rights (1981, Article 13). The right to democracy is closely related to what is known as the human right to vote. The close relationship between human rights to vote and commitment to democratic governance has been repeatedly emphasized by international and regional human rights bodies (Franck, 1992). Illustrative examples include the announcement by the Human Rights Committee (1996) that the provisions of the ICCPR that protect the right to vote are at the "core of democratic governance." Also, statements made in various resolutions were adopted by the UN Commission on Human Problems at that time. The right $(\mathrm{CHR})$ and the UN General Assembly add substance to the mutual dependence of human rights to vote and the right to democracy (for example, UN 2000, 2001).

\section{Bibliography}

\section{Books}

Bhagwati, J. N. (2002). Democracy and Development: Cruel Dilemma or Symbiotic Relationship. Review of Development Economics, Wiley Blackwell, vol. 6(2). Convention for the Protection of Human Rights and Fundamental Freedoms as amended by Protocol No. 11, Rome, 4 November 1950 http://conventions.coe.int;

Ezetah, R. (1997). The right to democracy: a qualitative inquiry. Brooklyn Journal of International Law.

Falk.R A and Strauss, A. (2000). On the Creation of a Global Peoples Assembly: Legitimacy and the Power of Popular Sovereignty. Stanford Journal of International Law 191.

Fox, J. (2007). Do Democracies Have Separation of Religion and State?. Canadian Journal of Political Science.

Held, D.(1995). Democracy and the Global Order. California: StanfordUniversity Press.

International Covenant on Civil and Political Rights, G.A. res. 2200A (XXI), 21 U.N. GAOR Supp. (No. 16) at 52, U.N. Doc. A/6316 (1966), 999 U.N.T.S.171, entered into force Mar. 23, 1976

McFaul, M. (2004) Democracy promotion as a world value, The Washington Quarterly, 28:1.

Przetacznik, F. (1991). The Basic Collective Human Right to Self 
Determination of Peoples and Nations as a Prerequisite for Peace. NYLS Journal of Human Rights, Vol. 8.

Recommendation 1444 (2000), Doc. 8700 of 5 April 2000, Opinion of the Committee on Legal Affairs and Human Rights, http://stars.coe.fr/doc/doc00/edoc87 00.htm; and Decision of 13 January 1997 , http://stars.coe.fr/act/compress/cp9 7/11f(97).htm.

Reisman, M. (2000). Sovereignty and Human Rights in Contemporary International Law,in Gregory Fox and Brad Roth, eds., Democratic Governance and International Law. Pp.,251-258. Cambridge: Cambridge University Press.

Russett, B. (1997). An Agenda for Peace 1995. By Boutros Boutros-Ghali. 2d ed. New York: United Nations.

Stiglitz, J. E. (2003). Globalization and its discontents. New York: W.W. Norton.

Singer, P. W. (2002). Corporate warriors: The rise of the privatized military industry. Ithaca: Cornell University Press.

Stromseth, J. E. (1992). Self-Determination, Secession and Humanitarian Intervention by the United Nations. Proceedings of the ASIL Annual Meeting.

U.N. Hum. Rts. Comm'n [HRC], General Comment No. 25: The Right to Participate inPublic Affairs, Voting Rights and the Right of Equal Access to Public Service, art. 11,
U.N.Doc. CCPR/C/21/Rev.1/Add.7 (Dec. 7, 1996).

Universal Declaration of Human Rights, G.A. res. 217A (III), U.N. Doc $\mathrm{A} / 810$ at 71 (1948). 